\title{
A Research and Education Project for Women in the Dominican Republic
}

\section{Moema Viezzer ${ }^{2}$}

\section{Research with a social purpose}

Research in the social sciences is rarely conducted with the aim of providing results which can be used by the groups who have been the object of that research. Academic research, even in cases where participant observation and similar techniques are employed, is almost always carried out to further the interests of the researcher. Even when studies are ostensibly directed to nonacademic objectives and undertaken by governmental or para-governmental institutions, international organisations etc., the human groups under scrutiny invariably have the same function: to provide information and to wait for the solutions to come from above ... if and when they do come.

The social researcher generally reproduces, in relation to the cultural and social patrimony of the people studied, the same unequal exchange that capitalist businessmen promote when they take raw materials from our countries at nominal prices in order to manufacture and market them beyond the control of the producer. The researcher goes to the field with his/her project which has been prepared in his/her institution or organisation, in accordance with his/her own interests. $\mathrm{S} /$ he gathers information during months, even years, in the field, such information being freely provided by workers, peasants, indians, slum-dwellers, etc. S/he bids farewell to the people $s /$ he has researched and returns to 'his/her world' to process the data, to interpret and utilise it in accordance with the needs of the intellectual elite to which $s$ /he belongs, the institution which $s /$ he serves. and of his/her own academic career.

And what happens to the people studied? Our countries of Latin America, Asia and Africa are full of research projects carried out by sociologists, anthropologists, ethnologists, economists, both national and foreign but mainly the latter (usually

\footnotetext{
1 The project was carried out during $1977 / 78$ by the author and Magaly Pineda.

2 Editors note:

The method of conscientization used in this project was based on that developed earlier by Moema Viezzer in her work in Bolivia, which is described in $S i$ me permiten Hablar -. now available in English under the title The Testimony of Domitila, a woman of the Bolivian mines 'Let me Speak!" (Domitila Barrios de Chungara with Moema Vlezzer, Monthly Review Press, 1978).
}

from the United States or Europe), who wish to study our society. But what are the results of this research for the people who have been studied?

Social science research in Latin America today when it is not carried out by international organisations or institutions, primarily serves the interests of university departments, movie or television companies, the intellectual clientele of Europe and the United States and the miniscule intellectual elite of our dependent capitalist countries. The studies which return to their original data gathering grounds are few and far between.

\section{A methodology which seeks to join theoretical with practical work}

We firmly maintain that the data gathered in social science research should be used:

- to promote more rigorous theoretical analysis;

-to develop educational projects for the group studied or for others who live in similar circumstances.

This has several implications. Those who are the object of research should become the subjects of the same, through their utilisation, assimilation, criticism and enrichment of the data. In other words, the results of research should be directed to the groups studied so that they may acquire more complete knowledge of the system in which they live in order to transform it to their own benefit.

Ways of conducting research must be reconsidered, as must the way in which data are processed and organised. Must data gathered in field work be presented only in texts of the highest level of theoretical abstraction which only a tiny intellectual elite can understand? Should the same research material not be elaborated in different ways, at different levels of abstraction for use by groups which have different levels of knowledge? For example, a woman factory worker has the right to interpret in her own way her situation of exploitation within the context in which she lives, even though her understanding of this and her subsequent action will not be the same as that of a woman intellectual, or a leader of an organisation. 
The vertical and isolationist way of operating that characterizes much of social science research must be changed. No researcher can undertake alone all the tasks implicit in this kind of research; interdisciplinary work is required. In addition, the intellectual researcher must be committed to defending the cause of liberation and be linkeddirectly or inderectly - with those organisations which exist to promote economic, social and political change.

\section{The research and education project for women in the Dominican Republic}

To date there is still no organisation within the Dominican Republic which can bring together women workers, peasants and slum-dwellers to defend their interests as exploited and oppressed women. Neither has any research been undertaken to gather data on the actual situation of Dominican women of various economic strata or on women in general. The few studies which do exist are partial and in the main related to questions of fertility and population control; the findings of these studies have not been passed on to the women of the sectors studied. At the same time those grass-roots organisations and institutions which are becoming increasingly involved in working with women are faced with an absence of studies and materials which they can use in their educational work. The need for such materials served as the basis for this research and education project, as did the knowledge that there is a need to study in greater depth the situation of Dominican women so as to work toward a process of consciousness raising and, organisation which will ensure that women become an important element in the process of social change.

Our research-education project for women was conceived on the basis of the principles elaborated above, and our specific goals were defined as follows

- to elaborate educational material on the basis of research into the situation of women whether as workers in urban or rural areas, as housewives in rural areas or poor city neighbourhoods, or as domestic employees;

-to make available to these women the results of the research, already partially elaborated, as a contribution to their own efforts to understand their own lives and to organise themselves;

-to incorporate into the final report of the project those comments, criticsms and recommendations which were made by the women themselves in the course of discussing the results of the research. 


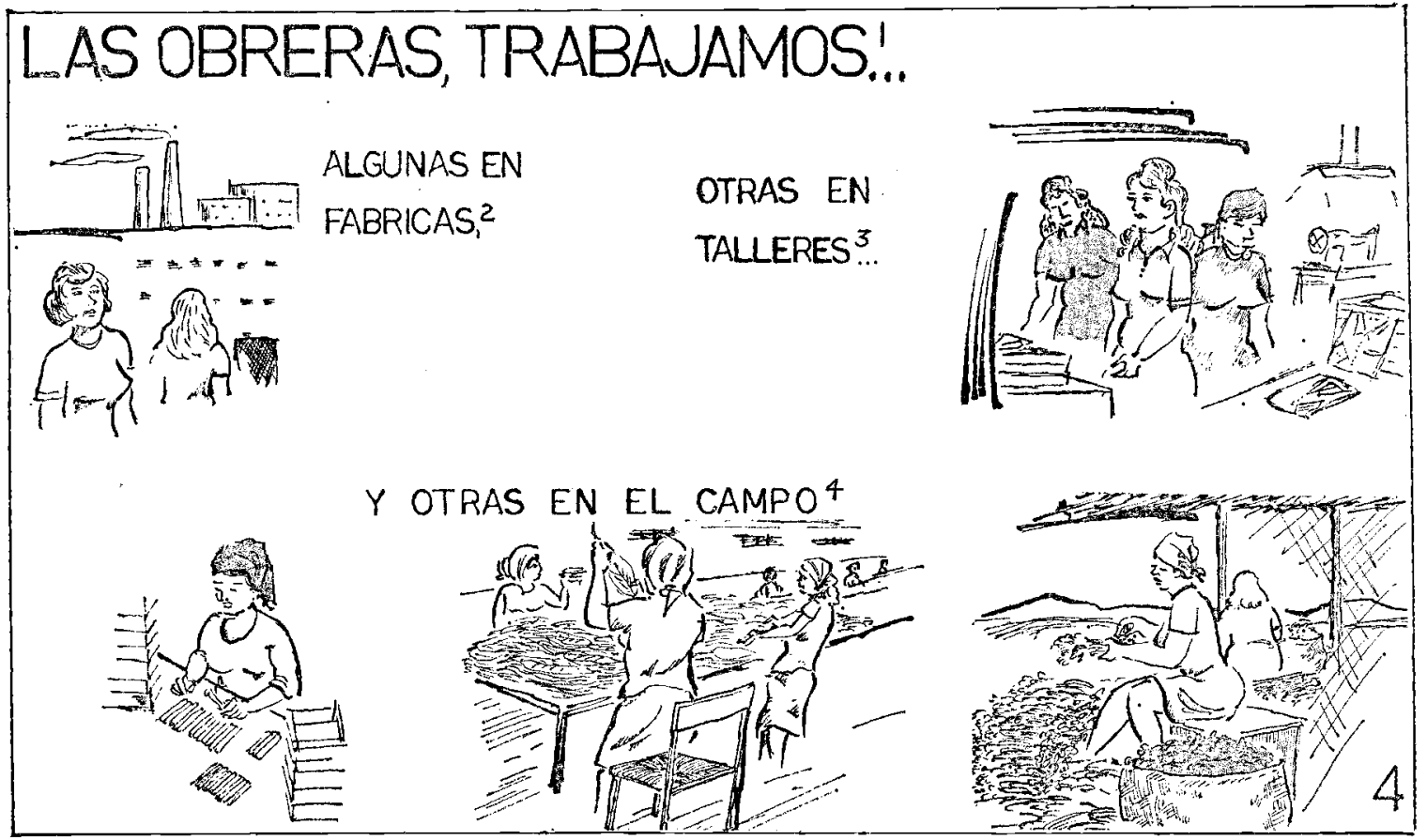

1. AS WORKERS, WE WORK . .

3. IN WORKSHOPS ...

2. IN FACTORIES . . .

4. AND IN THE COUNTRYSIDE

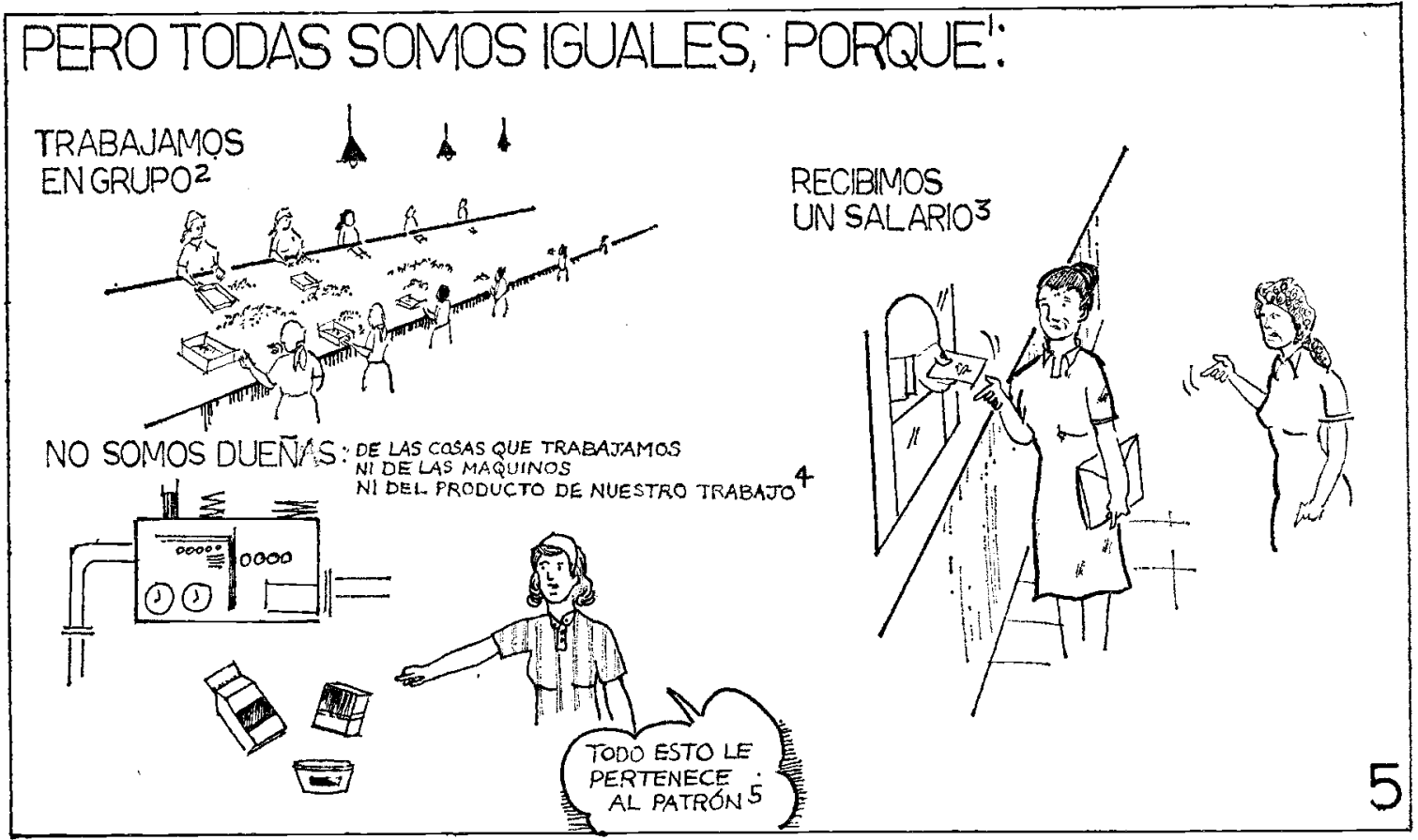

1. BUT WE ARE ALL THE SAME, BECAUSE:

2. WE WORK IN A GROUP

3. WE GET A WAGE

1 This is a translation of part of one of the educational texts prepared by the research and education project for women in the Dominican Republic as an example of the grass-roots work which was described and discussed at the Conference.
4. WE DON'T OWN: the materials we work with, nor the machines, nor the things we produce.

5. All these things belong to the boss.

Other educational material included nine testimonial statements from women working in different sectors of the economy, four notebooks, a play, and an audio-visual presentation. 


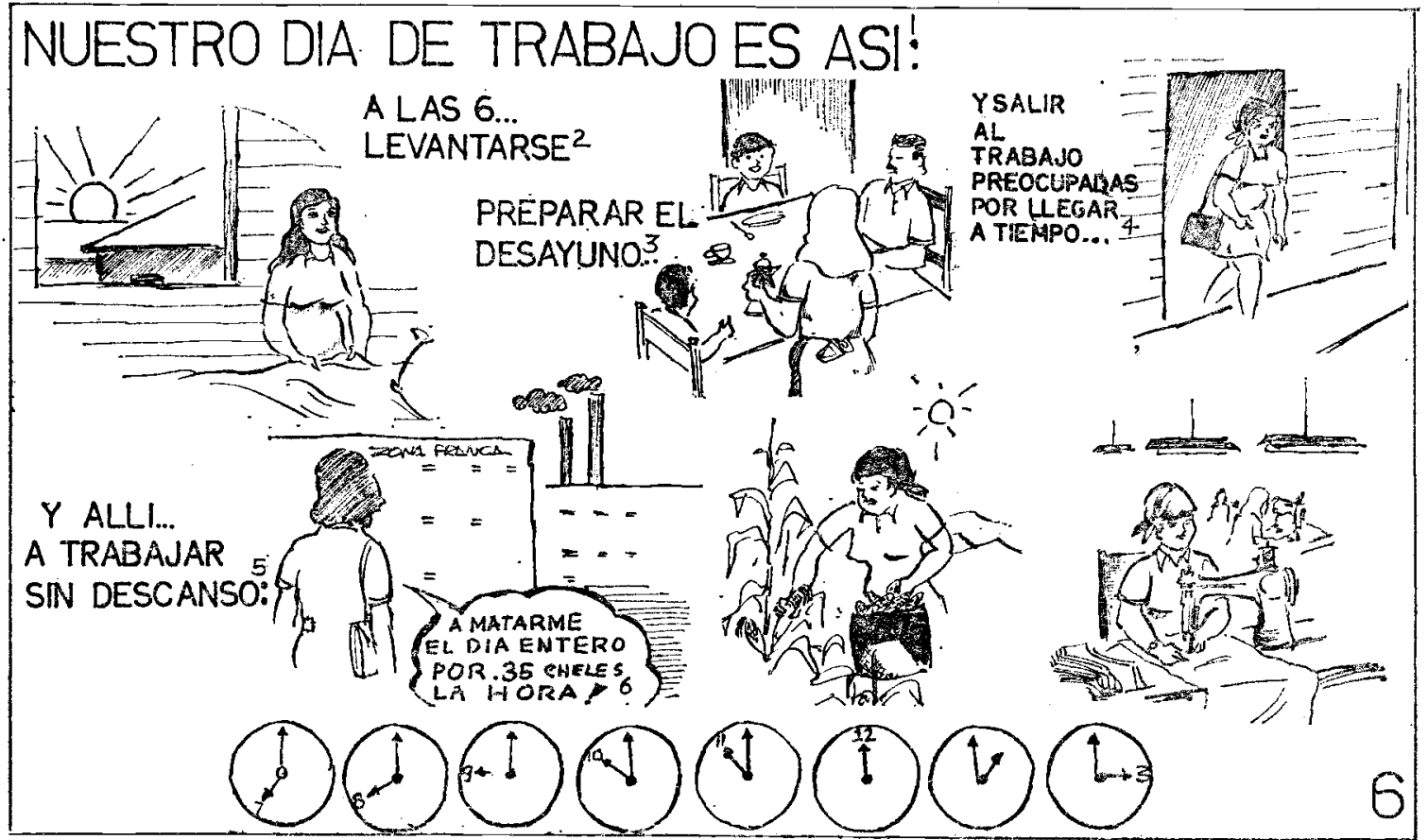

1. THIS IS WHAT OUR DAY IS LIKE:

2. AT 6 WE GET UP

3. MAKE BREAKFAST

4. AND LEAVE FOR WORK A LITTLE WORRIED ABOUT GETTING THERE ON
TIME ...

5. AND ONCE THERE . . W WE WORK WITHOUT REST

6. We work hard all day long for only 35 cheles an hour!

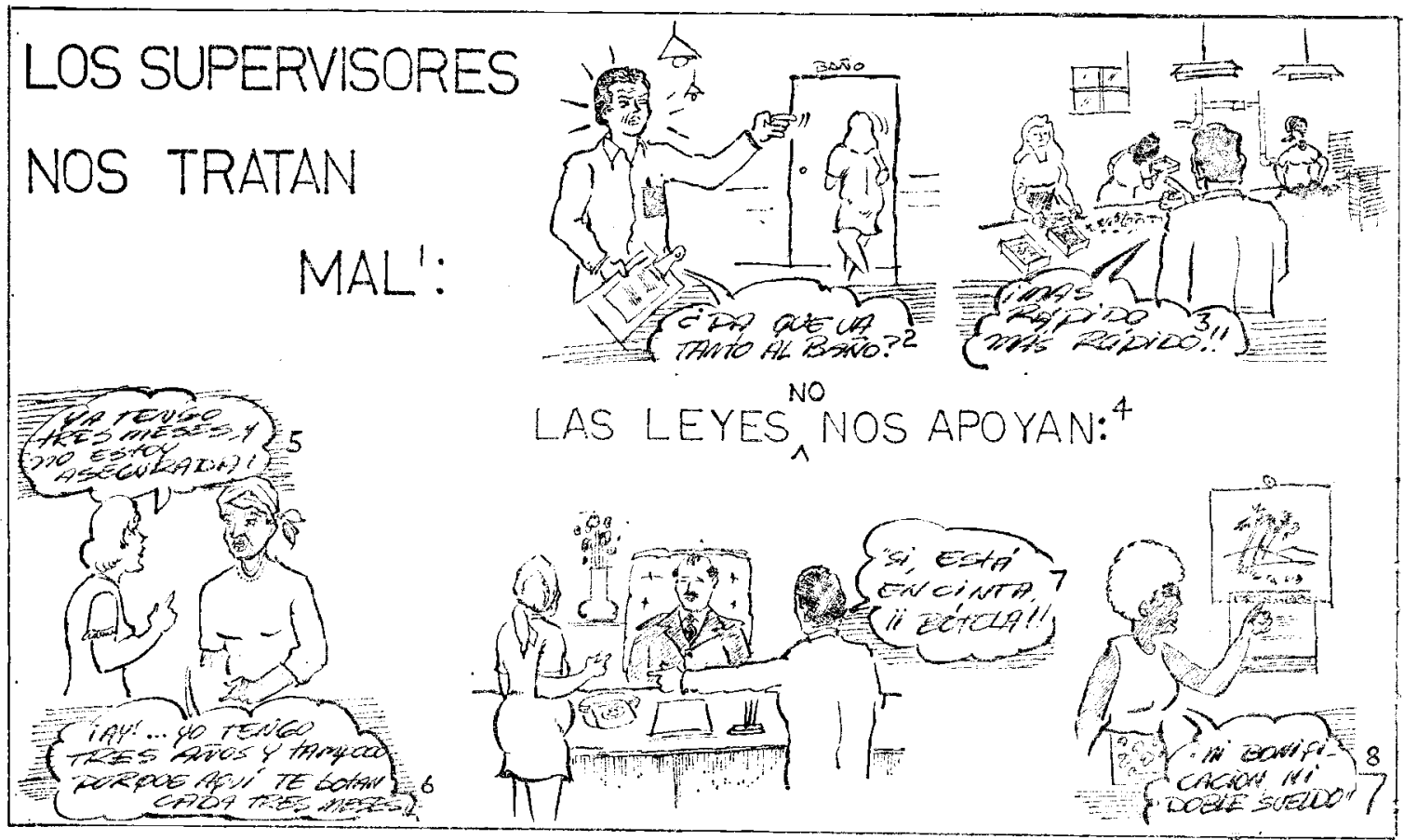

1. THE FOREMEN TREAT US BADLY:

2. Why is she going to the WC so often?

3. Faster, faster

4. THE LABOUR LAWS DON'T SUPPORT US:

5. I've been here 3 months and I'm still not able to claim my social benefits
6. Me too, but I've been here 3 years and I'm still not covered because they throw us out every 3 months

7. Yes, she's pregnant, fire her

8. No Christmas bonus nor the two months' wages we have a right to 


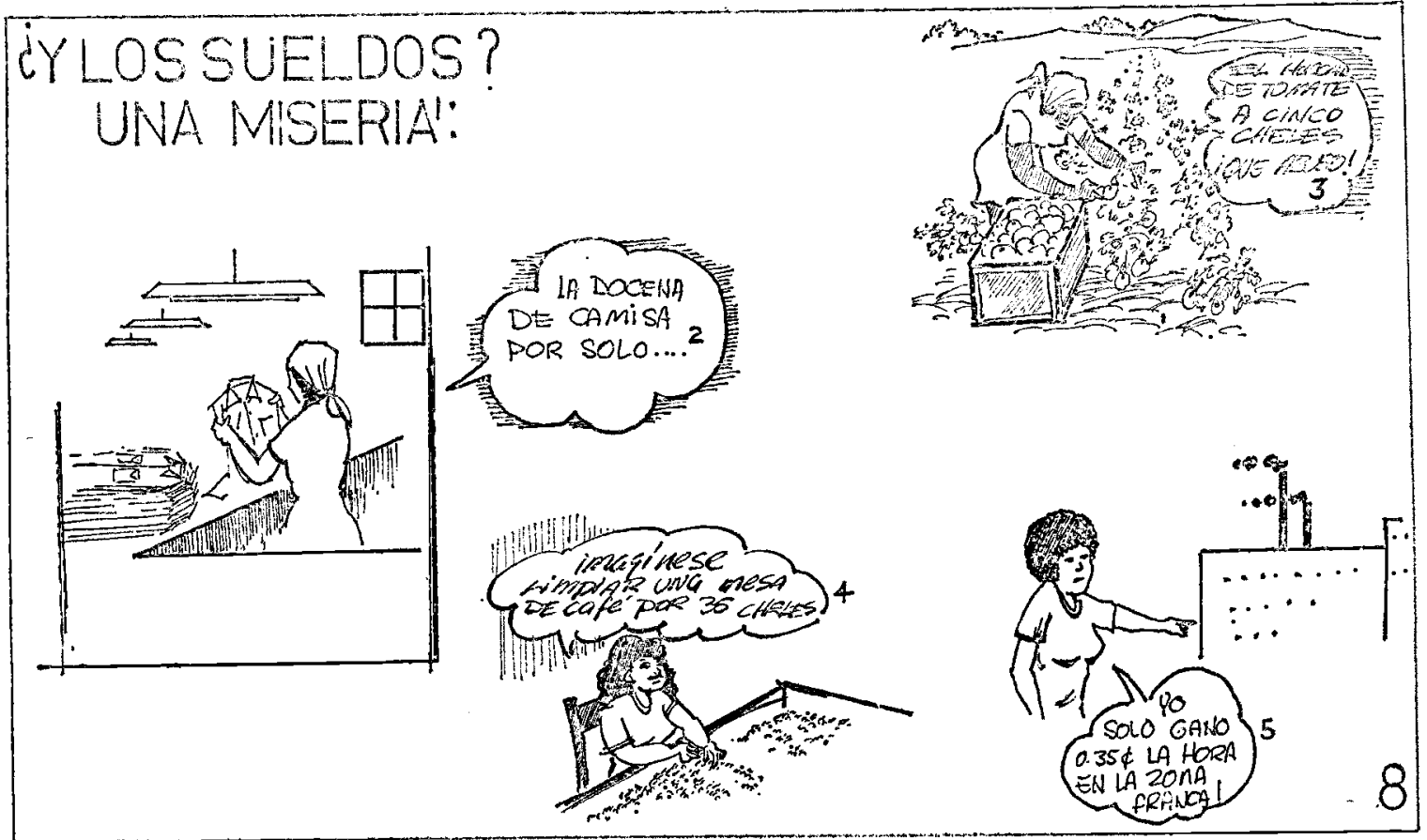

1. AND OUR WAGES-A PITTANCE:

2. A dozen shirts for only ...

3. Picking tomatoes for only 5 cheles, what a scandal
4. Imagine cleaning a tub full of coffee beans for only 35 cheles

5. And I only get 35 cheles an hour in the Free Trade Zone.

\section{MIENTRAS OEFERAS YOBREROS YOUNUVEUUO NOS MATAMOS PORUNAS HILACHAS!...
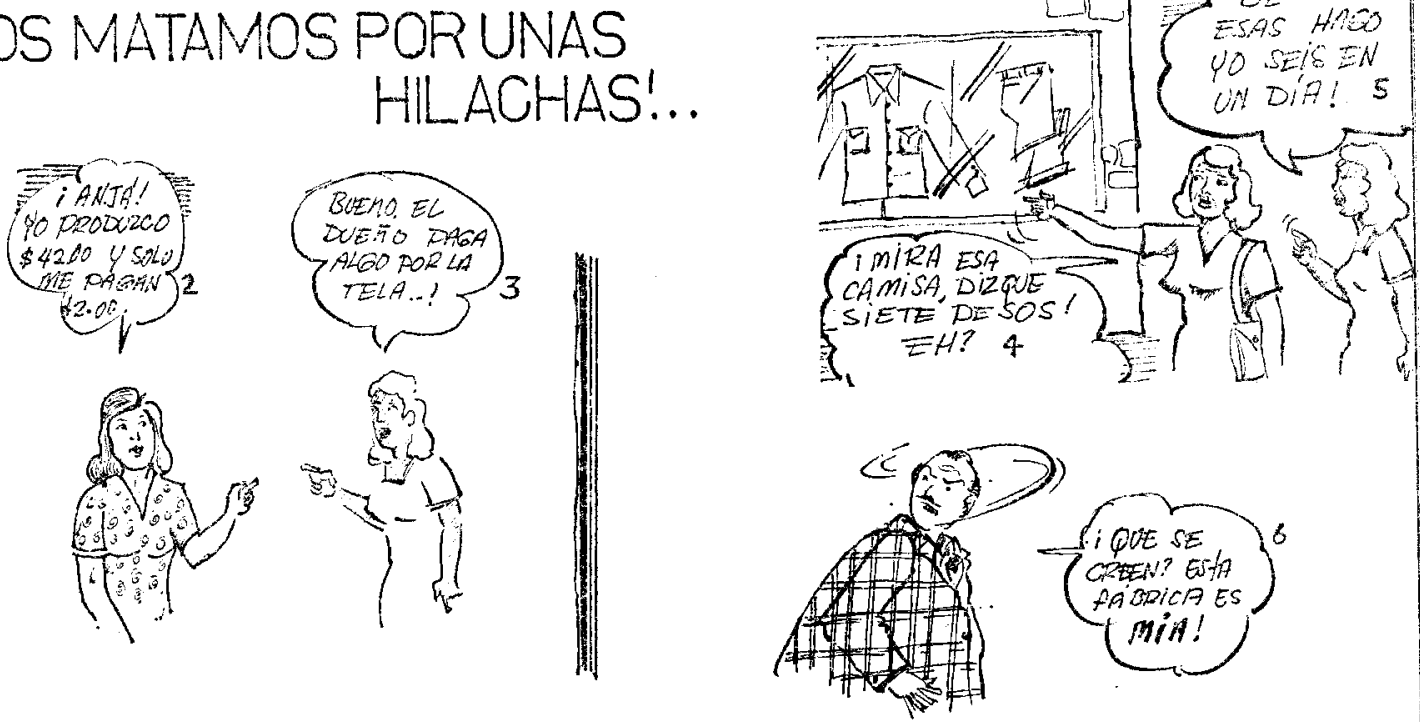

YASI EL. PATRON ENGORDA SU

1. WHILE WORKERS--MEN AND WOMEN ALIKE-WORK THEMSELVES TO DEATH FOR A FEW PENCE

2. Look, I produce $\$ 42.00$ worth of work but they only pay me $\$ 2.00$

3. But the boss has to pay something for the cloth

4. Look at these shirts-7 pesos each
5. I make 6 of those a day!

6. What are these people getting at? This factory is mine.

7. THIS IS HOW THE BOSS GETS A FAT BANK BALANCE THROUGH OUR EFFORTS. 
ESA EXPLOTACION LA SUFRIMOS TODOS LOS OBREROS Y OBRERAS PERO ADEMAS LAS OBRERAS TENEMOS OTROS TIPOS DE PROBLEMAS "POR EL HECHO DE SER MUUER"I

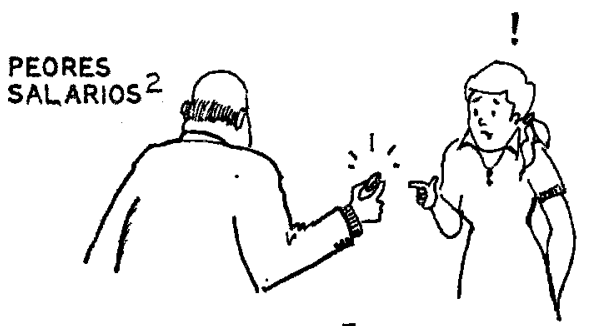

FALTA DE PROTECCION LEGAL 5
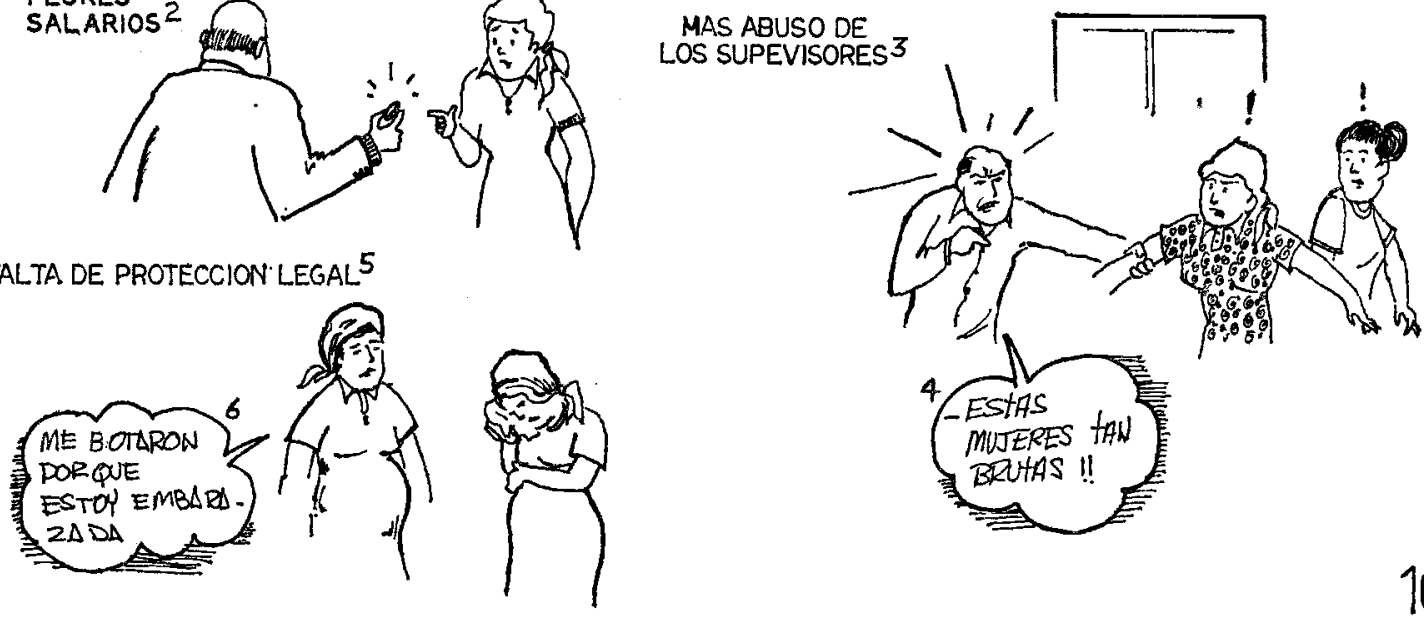

10

1. THIS EXPLOITATION AFFECTS ALL WORKERS, MEN AND WOMEN ALIKE, BUT AS WOMEN WORKERS WE HAVE OTHER PROBLEMS JUST BECAUSE WE ARE WOMEN:
2. LOWER WAGES

3. MORE ABUSE FROM THE SUPERVISORS

4. These stupid women!

5. LACK OF LEGAL PROTECTION

6. They fired me because I'm pregnant.

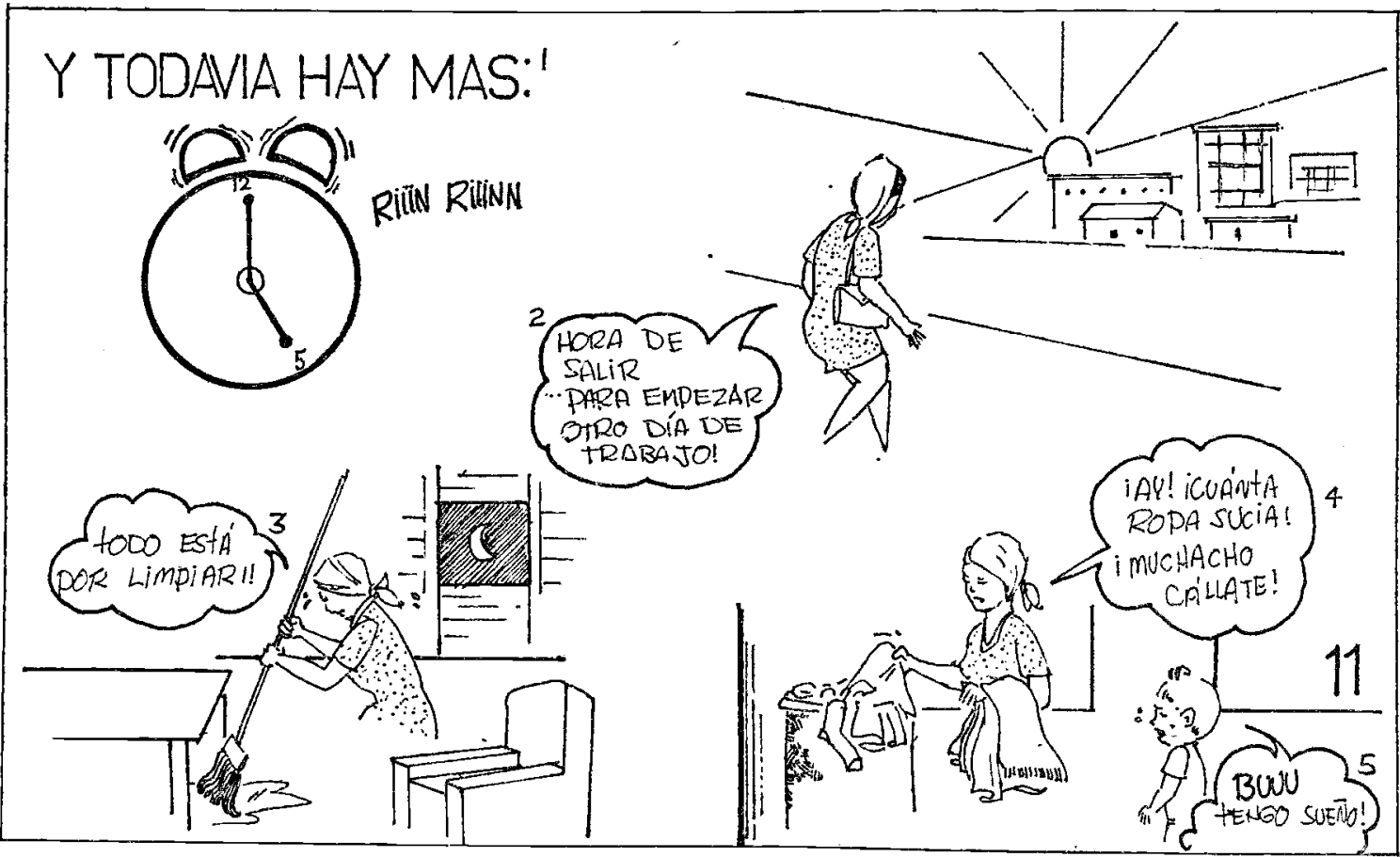

1. AND THERE IS STILL MORE TO COME

2. It's time to leave to start another day's work

3. Everything's got to be cleaned
4. Oh what a lot of filthy clothes shut up!!

5. Waaaa.

I'm tired. 
Asi, CADA dia de la OBRERA ES UNA "DOble JORMADA"

DE TRABAJO:'

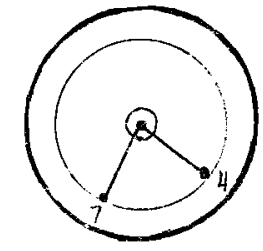

DE 7 A 4 EN LA FÁBRICA o en EL CAMPO...2

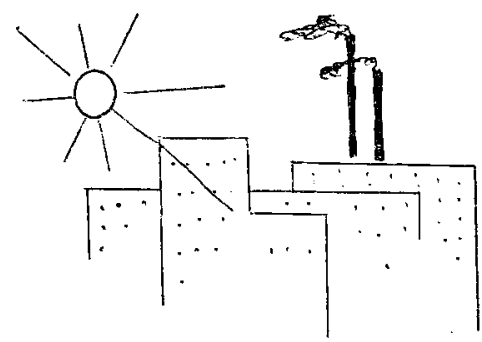

1. SO A WORKING WOMAN'S DAY IS ALWAYS A DOUBLE DAY

2. FROM 7 TO 4 IN THE FACTORY OR THE

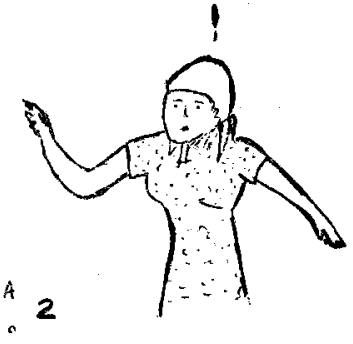

Y DE 4 A.... ¡SABE DIOS HASTA que HORA!... EN la casa 3

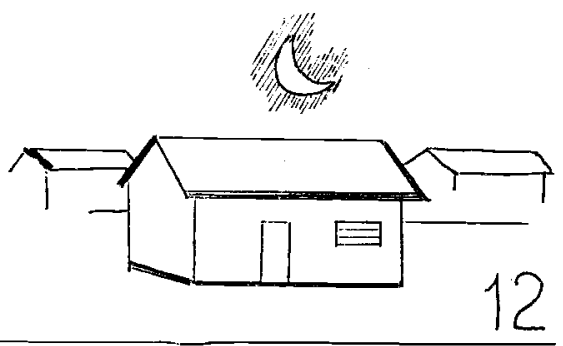

FIELDS . .

3. AND FROM 4 TO GOD KNOWS WHAT TIME AT HOME.

¿Y QUE PODEMOS HACER?'
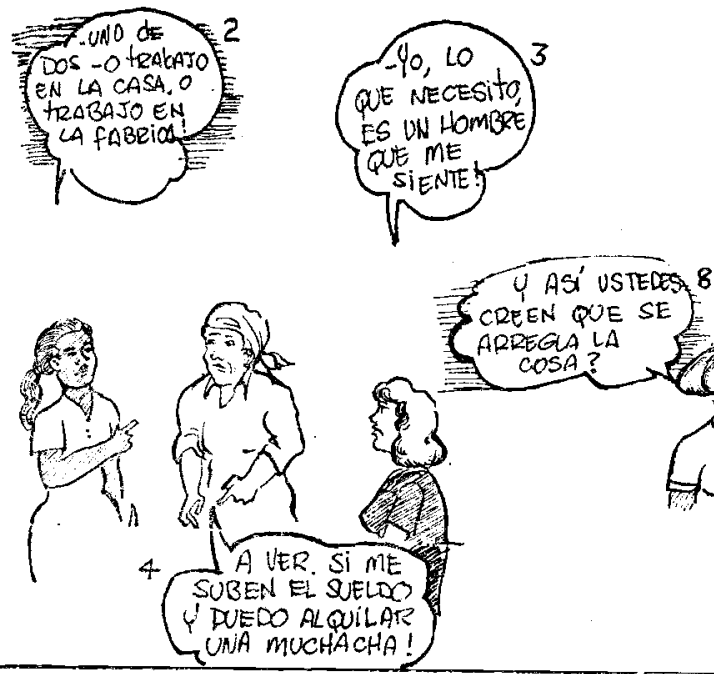
$\Rightarrow$ CREEN QOE SE ARREGL LA $\cos A ?$
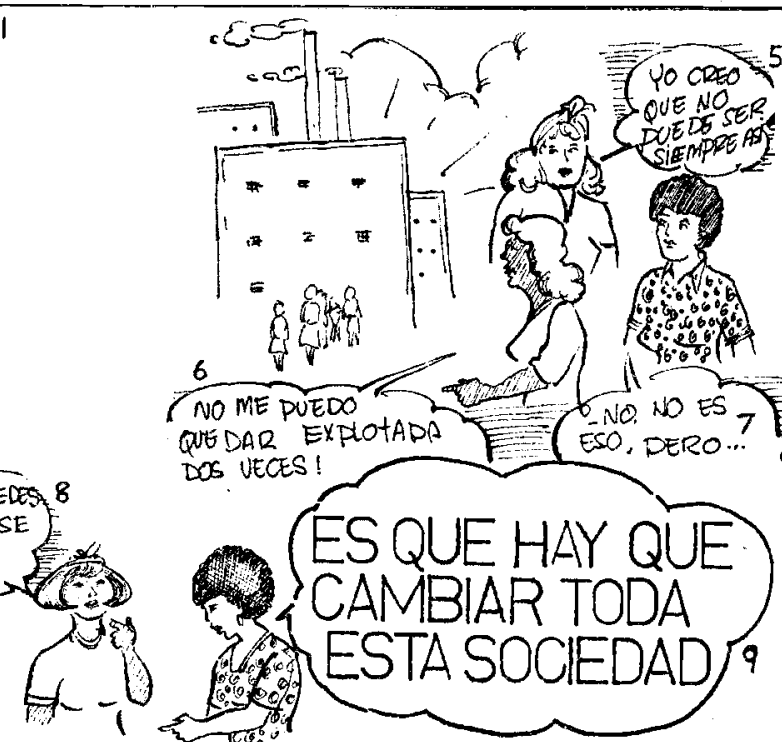

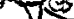
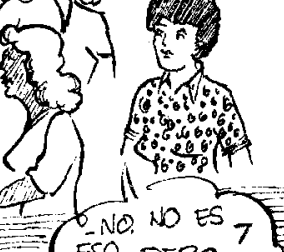

DOS VECES

(ES QUE HAY QUE)

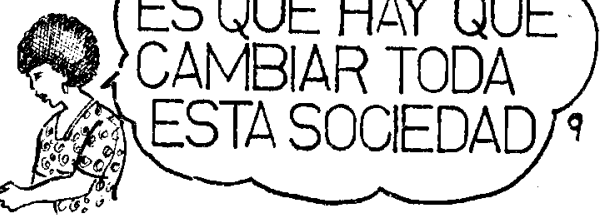

1. AND WHAT CAN WE DO ABOUT THIS?

2. One thing or the other-either I work at home or in the factory.

3. What I need is a man who listens to me.

4. If they would only increase my wages I could get a maid.
5. I don't think it's always got to be like this.

6. I can't just let them exploit me twice over.

7. No, it's not that, but ...

8. Do you think things will change this way?

9. WHAT WE'VE GOT TO DO IS CHANGE SOCIETY. 